\section{РАДІАЦІЙНА ФІЗИКА} RADIATION PHYSICS

УДК 539.125.5

https://doi.org/10.15407/jnpae2021.02.149

\author{
O. P. Artykulnyi ${ }^{1,2, *}$, M. M. Avdeev², Ye. M. Kosiachkin ${ }^{1,2,3}$, \\ V. I. Petrenko ${ }^{4,5}$, I. Safarik ${ }^{6}$, L. A. Bulavin ${ }^{1}$ \\ ${ }^{I}$ Taras Shevchenko National University of Kyiv, Kyiv, Ukraine \\ ${ }^{2}$ Joint Institute for Nuclear Research, Dubna, Russia \\ ${ }^{3}$ Institute for Scintillation Materials, National Academy of Sciences of Ukraine, Kharkiv, Ukraine \\ ${ }^{4}$ BCMaterials, Basque Center for Materials, Applications and Nanostructures, 48940 Leioa, Spain \\ ${ }^{5}$ Ikerbasque, Basque Foundation for Science, 48009 Bilbao, Spain \\ ${ }^{6}$ Department of Nanobiotechnology, Biology Centre, ISB, CAS, Ceske Budejovice, Czech Republic \\ *Corresponding author: artykulnyi@gmail.com
}

\title{
NEUTRON INVESTIGATION OF INTERACTION \\ BETWEEN ANIONIC SURFACTANT MICELLES \\ AND POLY (ETHYLENE GLYCOL) POLYMER BRUSH SYSTEM
}

A polymer brush system of a neutral polymer poly (ethylene glycol) with a molecular weight of $\mathrm{M}_{\mathrm{w}}=20 \mathrm{kDa}$ on silicon substrates in an aqueous medium was studied by the specular neutron reflectometry. Structural changes in the density profile of a polymer brush caused by the interaction of polymer chains with micelles of the anionic surfactant dodecylbenzenesulfonate acid were observed. The effect is shown to be related to the formation of molecular polymer-micelle associates in the bulk of the solution, which was previously studied by small-angle neutron scattering in a wide range of surfactant concentrations at various molecular weights of the polymer. The density of the dry polymer layer on the silicon substrate was additionally characterized by X-ray reflectometry and scanning atomic force microscopy.

Keywords: micelles, anionic surfactants, poly (ethylene glycol), neutron reflectometry, polymer brush, small-angle neutron scattering.

\section{Introduction}

Polymer brush systems are polymer chains densely tethered to the substrate surface by strong covalent bonds. The polymer molecules could be extremely stretched from the interface, thus forming a polymer palisade that remains more stable than the polymer layer formed by physisorption [1]. There are two approaches to creating a covalently tethered po-lymer layer on surfaces: 1) through a chemical reaction of the functionalized polymer end-group with complementary functional groups deposited on the surface ("grafting to") [2]; 2) by carrying out a polymerization reaction of monomers from a solution near the surface modified by initiator groups (surfaceinitiated "grafting from"). These methods may differ significantly in the resulting parameters of the polymer brush system; thus, the polymer layer synthesized by the "grafting from" method has a higher density, while the "grafting to" method is distinguished by the simplicity of the synthesis procedure and the monodispersity of polymer chains [3].

Micellar systems of anionic surfactant solutions can interact with polymers. In the case of neutral polymers, the surfactant-polymer interaction is weak, which is caused by the number of factors responsible for minimizing the free energy of the mixed micellarpolymer system. These factors include the minimization of the contact surface of the hydrophobic micellar core with a polar solvent and the screening of the electrostatic repulsion of the polar groups due to the polymer chain incorporation into the structure of the micelle shell [4]. As a result of this interaction between the polymer molecule and micelles, surfactantpolymer associates (aggregates of surfactant molecules in the form of micelles binding to the polymer chain) appear. The corresponding process of formation of polymer-surfactant associates is also called the micelle binding process by a polymer chain.

The free energy of micelle binding can be estimated by the expression

$$
\Delta G=-k_{b} T \ln \frac{C M C}{C A C}
$$

where $k_{b}$ is the Boltzmann constant; $T$ is the absolute temperature; $C M C$ is the critical micelle concentration; $C A C$ is the critical aggregation concentration, at which the complexes begin to form. The formation of surfactant-polymer associates occurs at $C M C>C A C$.

(C) O. P. Artykulnyi, M. M. Avdeev, Ye. M. Kosiachkin, V. I. Petrenko, I. Safarik, L. A. Bulavin, 2021 
In recent decades, there has been a significant increase in interest in studies of the surfactant-polymer association in aqueous solutions [5]. In particular, they include the investigations employing the methods of structural analysis based on nuclear physics experiments [6]. Thus, the method of small-angle neutron scattering (SANS) was successfully used to determine the structure and interaction parameters of the anionic surfactant dodecylbenzensulfonic acid (DBSA) micellar system in the presence of polyethylene glycol (PEG) [7, 8]. Nevertheless, the question of surfactantpolymer interaction in a dense polymer medium of polymer brushes remains topical. This issue is closely related to the problem of modifying the surfaces of colloidal systems [9] and manipulating their properties due to the surfactant-polymer interaction [10]. Also, the DBSA surfactant is used as a stabilizer of waterbased magnetic fluids for biomedical application [11], where the water-soluble polymer, poly (ethylene glycol), is often used to increase the biocompatibility of magnetite particles and prolong the time of particle circulation in the body [12].

A well-known effect of the interaction of anionic surfactant micelles such as sodium dodecyl sulfate with polymer brush system of polyethylene oxide [13, 14]. Thus, the authors [13] investigated changes in the density distribution profile of a PEG polymer brush during the adsorption of sodium dodecyl sulfate by the optical reflectometry method, where the dependences of the adsorption of micelles on the length of the polymer chain, the grafting density, as well as the dependence on the parameter of the ionic strength of the solution of micelles, which is the determining factor in the process of aggregation of micelles with the polymer, were studied. The theoretical model of the polymer density distribution profile in the composition of the polymer brush during the adsorption of ionic surfactant micelles was described by the authors [15] in the framework of the self-consistent field approximation. Thus, the ability to form surfactant-polymer complexes in the bulk of the solution plays a significant role in the behavior of polymer brushes in surfactant solutions. The structure of sodium dodecyl sulfate micelles in a dense medium of a polymer brush of a weak polyelectrolyte poly dimethylaminoethyl methacrylate was investigated by neutron reflectometry, where the formation of cylindrical micelles and periodic layered structures of lamellae was observed [16].

In the present work, PEG polymer brush systems synthesized by the "grafting to" method on the surface of a flat silicon substrate and its response to the surfactant-polymer interaction in a DBSA micellar solution, were studied. For these purposes, we used neutron and X-ray reflectometry for a PEG polymer brush in solutions of an anionic surfactant DBSA. It is assumed that the determining factor in the changes in the polymer brush density profile is the effect of the formation of complexes between PEG and DBSA, which we previously studied using the SANS method $[7,17]$. Using the CMC and CAC values obtained from measurements of the surface tension of DBSA solutions [7], we estimate the complexation energy of micelles per one surfactant molecule $\Delta G=-1.5 k_{b} T$ for systems with $M_{w}=20 \mathrm{kDa}$ at polymer concentration 5 vol. \%. The dry polymer brush systems on a silicon substrate were additionally characterized by X-ray reflectometry (XRR) and scanning atomic force microscopy (AFM).

\section{Methods and materials}

Chemical-grade purity components of dodecylbenzenesulfonate (DBSA), (3-aminopropyl) triethoxysilane (APTES), methanol, poly (ethylene glycol) $\mathrm{M}_{\mathrm{w}}=20 \mathrm{kDa}$ (PEG), methoxy-poly (ethylene glycol) - succinimidyl carboxymethyl ester (mPEGNHS) were purchased in Sigma-Aldrich, deuterated water $\left(\mathrm{D}_{2} \mathrm{O}, 99.9 \%\right)$ was purchased in LLC "Astrachim" (St. Petersburg, Russia). To prepare samples of aqueous solutions, we used water purified with Millipore (Milli-Q) technology.

A silicon single crystal was used as a substrate (Crystal GmbH, Germany) with deposited layers of titanium (5 nm thick) and silicon oxide (50 nm thick) by vacuum magnetron sputtering (Ltd Mirrotron, Hungary). The sputtering titanium layer using as a carrier layer, which enhances the specular reflection signal and improves the signal-to-background ratio [18].

The synthesis of the polymer brush system was carried out in several stages following the protocol presented in [19]. First, to cleanse the crystal from organic contaminants and grow an oxide film, the crystal was placed in an aqueous solution of ammonia solution with hydrogen peroxide $(30 \%)$ in a ratio of $(5: 1: 1)$ at the temperature of $60^{\circ} \mathrm{C}$ for $15 \mathrm{~min}$, then the crystal was kept in concentrated sulfuric acid with the addition of hydrogen peroxide for $20 \mathrm{~min}$ at a temperature $100^{\circ} \mathrm{C}$. To activate the surface by functional groups, according to [20], the substrate was immersed in an APTES solution in dehydrated methanol in an inert argon atmosphere for $24 \mathrm{~h}$, then thoroughly washed with water and ethanol. Finally, an aqueous solution of mPEG-NHS was applied to the substrate surface and kept overnight in an inert argon atmosphere.

The control of the synthesized polymer layer was carried out by scanning atomic force microscopy using an NTEGRA atomic force microscope (NT-MDT, Spectrum Instruments, Russia) and X-ray reflectometry Empyrean (Malvern Panalytical, UK). 
The thickness and scattering length density (SLD) of the dry polymer layer were investigated by X-Ray reflectometry: beam from the air, $\theta-2 \theta$ scan, slit collimation. The reflectivity curve, squared modulus of the reflection coefficient, was measured as a function of the normal (relative to the substrate surface) component of the momentum transfer. The Fourier transform of the reflectivity curve in the Born approximation represents a dependence of the scattering length density profile on the distance from the surface (interface depth). The SLD contrast of the deposited PEG layer against the substrate was due to the difference in the X-ray SLDs of the polymer (SLD 10 $10^{-4} \mathrm{~nm}^{-2}$ ) and silicon ( $\mathrm{SLD} \mathrm{Si}=20.07 \cdot 10^{-4} \mathrm{~nm}^{-2}$ ). The expected thickness $(\mathrm{h} \sim 1 \mathrm{~nm})$ is within the instrument resolution. $\mathrm{A} \mathrm{Cu}$ tube was used as a source of X-rays $\left(\lambda\left(\mathrm{K}_{\alpha}\right)=0.154 \mathrm{~nm}\right)$.

The morphology of the dry polymer layer on the surface was studied by atomic force microscopy in the tapping mode. This scanning mode is optimal for soft matter samples as it is sensitive to the structure of the surface as compared to the non-contact mode; also, it is safer because of the short duration of the tip/surface contact. The height profiles of the surface were obtained and analyzed using an NT-MDT NSG01 tip (N-type silicon single crystal coated with gold; mean radius of $6 \mathrm{~nm}$; constant hardness of $5 \mathrm{~N} / \mathrm{m}$ ). The scanning speed was $0.3 \mathrm{~Hz} \times$ line, digital size of the AFM image was $512 \times 512 \mathrm{px}$.

The neutron reflectometry experiment was performed on the GRAINS reflectometer, beamline 10 of the IBR-2 pulsed reactor [21]. The instrument operates in the time-of-flight (TOF) mode. Reflected neutrons are detected by a ${ }_{2}^{3} \mathrm{He}$ position-sensitive detector. During the experiment, the cryogenic moderator with a temperature of $30 \mathrm{~K}$ was in operation (cold mode). This made it possible to obtain neutron spectra in the wavelength range of $0.1 \div 0.9 \mathrm{~nm}$ [22]. Corresponding momentum transfer $q$-range (normal component with respect to the planar surface) of $0.01 \div 0.2 \mathrm{~nm}^{-1}$. The experiment was carried out using a solid/liquid cell filled either with deuterated (heavy) water or with the solution of DBSA in heavy water. The substrate with a synthesized polymer layer was placed inside the cell [23]. Passing through the crystal, the neutron beam was reflected from the solidliquid interface, which provided a total reflection of neutrons, while $q^{2}<4 \pi(\Delta \rho)$, where $\Delta \rho-$ SLD contrast due to the difference in the neutron SLDs of silicon $\left(\mathrm{SLD}=2.074 \cdot 10^{-4} \mathrm{~nm}^{-2}\right)$ and heavy water $\left(\mathrm{SLD}=6.34 \cdot 10^{-4} \mathrm{~nm}^{-2}\right)$. The experimental curves were modeled using a genetic algorithm based on the Parratt formalism and realized in the MOTOFIT software [24].

\section{Results and discussion}

Let us introduce the parameter of the average distance between two tethering points of polymer endgroup attachment on the substrate surface $(D)$ and average polymer brush height $(h)$ as the distance from the free end of the polymer chain to the surface of the substrate, and then the structural definition of the polymer brush system can be written as follows:

$$
D<\sqrt{r^{2}}<h,
$$

where $\sqrt{r^{2}}$ - the root-mean-square distance between the ends of the polymer coil in solution. Systems that do not satisfy inequality (2) are called sparse grafted polymer brushes, or systems in the "mushroom" mode for which $h \sim \sqrt{r^{2}}$. The grafting density parameter $(\sigma)$ is estimated from the relation

$$
\sigma=\frac{M_{n}}{h \rho N_{a}},
$$

where $\rho$ is the bulk polymer density, $N_{a}$ is the Avogadro constant, $M_{n}$ is the polymer molecular weight. To designate the modes of polymer brush systems, the parameter of the reduced tethering density $(\Sigma)$ of polymer chains is introduced [3]:

$$
\Sigma=\frac{\pi R_{g}^{2}}{\sigma}
$$

where $R_{g}$ is the gyration radius of a polymer coil. The transition between the weakly interacting mode $(\Sigma<1)$, crossover mode $(1<\Sigma<6)$ and stretched brush mode $(\Sigma>6)$ can be distinguished.

The thickness of the synthesized polymer brush in the dry state $\left(h_{0}=1.7 \mathrm{~nm}\right)$ was determined from the approximation of the X-ray reflectometric curve (Fig. 1, a). The average distance between two adjacent polymer attachments to the substrate can be estimated as

$$
D=\sqrt{\frac{M_{n}}{h_{0} \rho N_{a}}},
$$

which is $4.4 \mathrm{~nm}$ for the synthesized polymer brush. Using the values of the radius of gyration $R_{g}=4.3 \mathrm{~nm}$, determined by the methods of dynamic light scattering and small-angle neutron scattering [25], it is possible to estimate the root-mean-square distance between the ends of the polymer coil $\sqrt{r^{2}}=\sqrt{6} R_{g} \sim 10.5 \mathrm{~nm}$. Thus, the system synthesized by us satisfies condition (2) for dense polymer brush systems. 
Parameters of the Ti and Si oxide deposition on a Si substrate were obtained from the analysis of the $\mathrm{X}$-ray reflectometry curve (Fig. $1, b$ ) obtained in the 'from air' geometry. The resulting values are $5 \mathrm{~nm}$ for

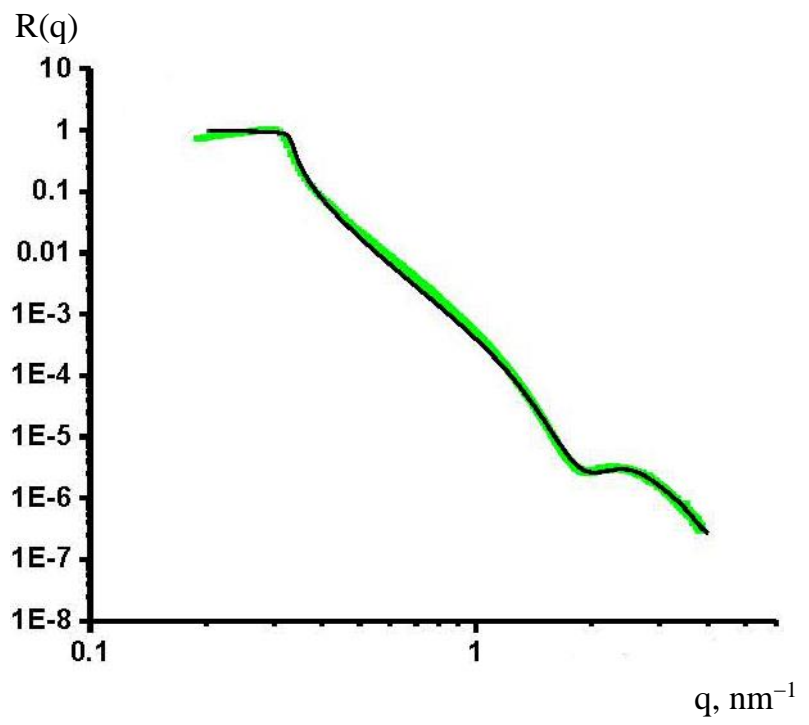

$a$ the thickness of the titanium layer and $50 \mathrm{~nm}$ for the thickness of the silicon oxide layer; roughness is about $0.5 \mathrm{~nm}$.

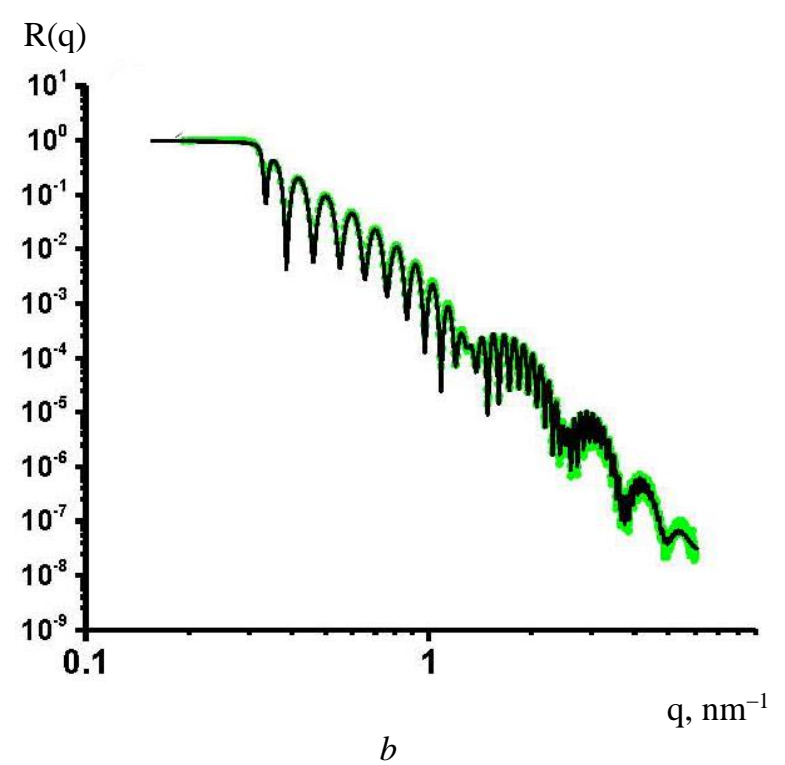

Fig. 1. X-ray reflectometry curves from dry PEG polymer brush on the silica $(a)$; from silicon crystal substrate with titanium supportive layer and silicon dioxide layer $(b)$. Solid lines show the approximating curves.

(See color Figure on the journal website.)

An example of AFM images for dry polymer brushes is shown in Fig. 2. The height profile slice shows a rather smooth surface of the polymer layer with a roughness repeating the roughness of the substrate surface (less than $1 \mathrm{~nm}$ ). At the same time, additional inhomogeneities presumably above the dense polymer layer are observed, which occupy about several percent of the polymer film area. They are sto- chastically distributed over the layer and appear to be polymeric structures that represent a kind of nuclei for the growth of the next polymer layer; their height ranges from 2 to $5 \mathrm{~nm}$. The AFM studies prove a good homogeneity of the dry polymer layer on the substrate, resulting in a well-resolved peak in the XRR curve (see Fig. 1, $a$ ).
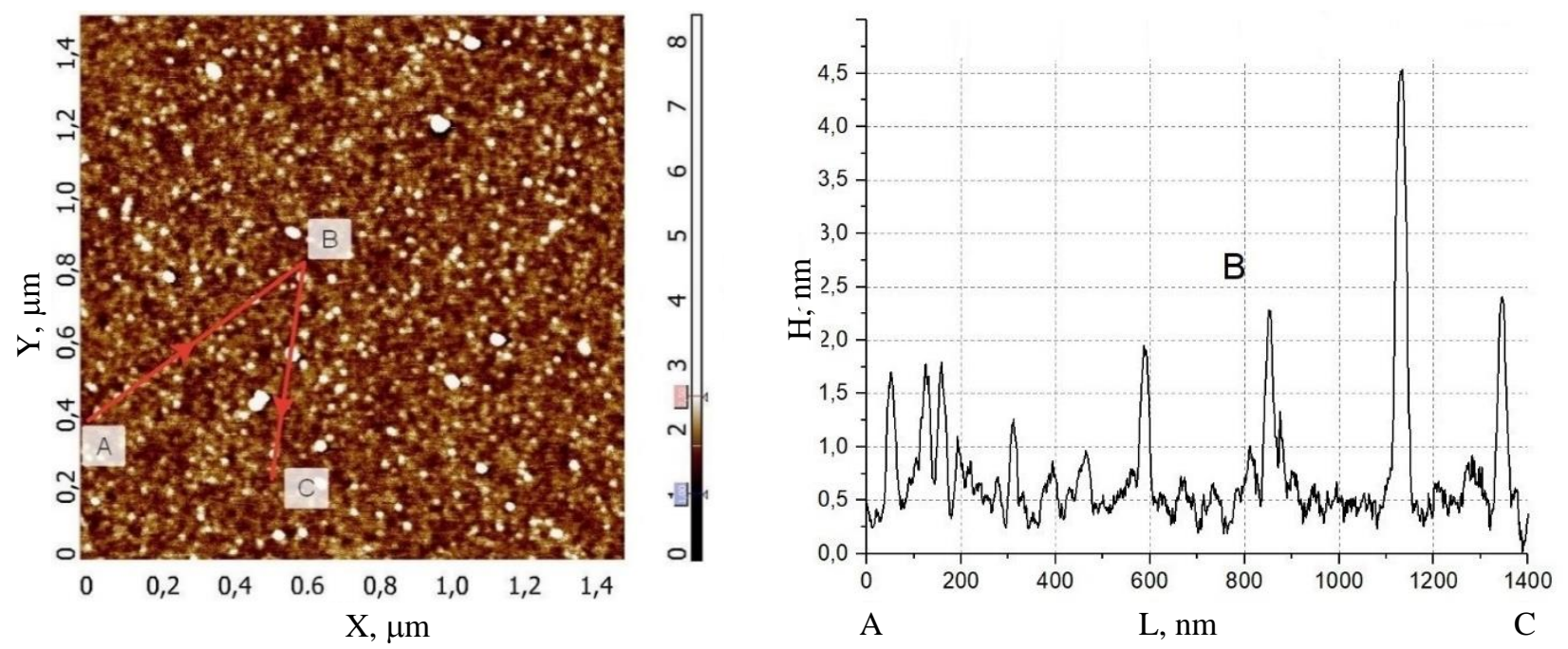

Fig. 2. Scanning atomic force microscopy image of the polymer layer (left), a line-cut profile of the polymer layer surface (right).

(See color Figure on the journal website.)

The neutron specular reflectivity curves obtained for different interfaces with the liquid components are shown in Fig. 3, $a$. They include (1) a substrate without a polymer brush in contact with pure heavy water, 
(2) a substrate with a PEG polymer brush in contact with pure heavy water and (3) a substrate with a PEG polymer brush in contact with a micellar solution of DBSA (concentration 0.2 vol. \%) in deuterated water. The reflectivity curves show oscillations with a period of about $\Delta q \sim 2 \pi / d$ determined by the thickness, $d$, of the $\mathrm{SiO}_{2}$ layer. The smoothing of the oscillations in the reflectivity curves in the region of large $q$-value for the samples with the PEG layer is indicative of the presence of a thin diffuse layer on the substrate surface. A certain shift of oscillations is observed after the addition of DBSA to the solution. This is explained by an increase in both the diffuse

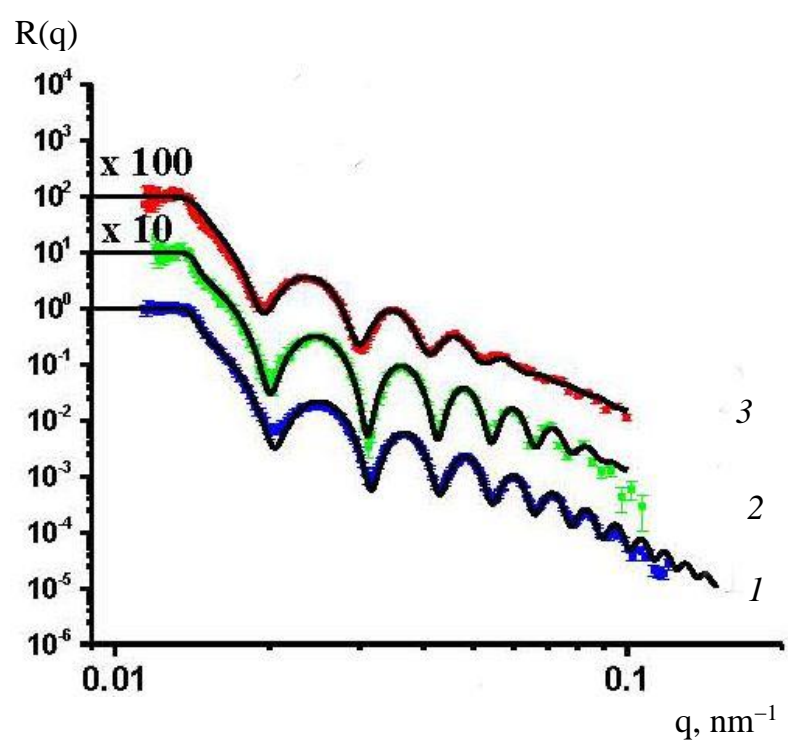

$a$ layer thickness and roughness of the polymer brush interface with the micellar solution of DBSA.

The neutron SLD profiles for the system with the polymer brush on the substrate derived from the reflectivity curves by modeling are given in Fig. 3, $b$. The parameters of the obtained polymer layer are $6.6 \mathrm{~nm}$ in height and $1.3 \mathrm{~nm}$ in roughness. Upon addition of DBSA to the solution, the height of the polymer brush increases to $9.2 \mathrm{~nm}$ with a roughness of $1.7 \mathrm{~nm}$. The estimated parameter of the reduced density of the attachment of polymer chains (4) shows that educed tethering density $\Sigma$ increases from 12.6 to 17.5 with the addition of DBSA.

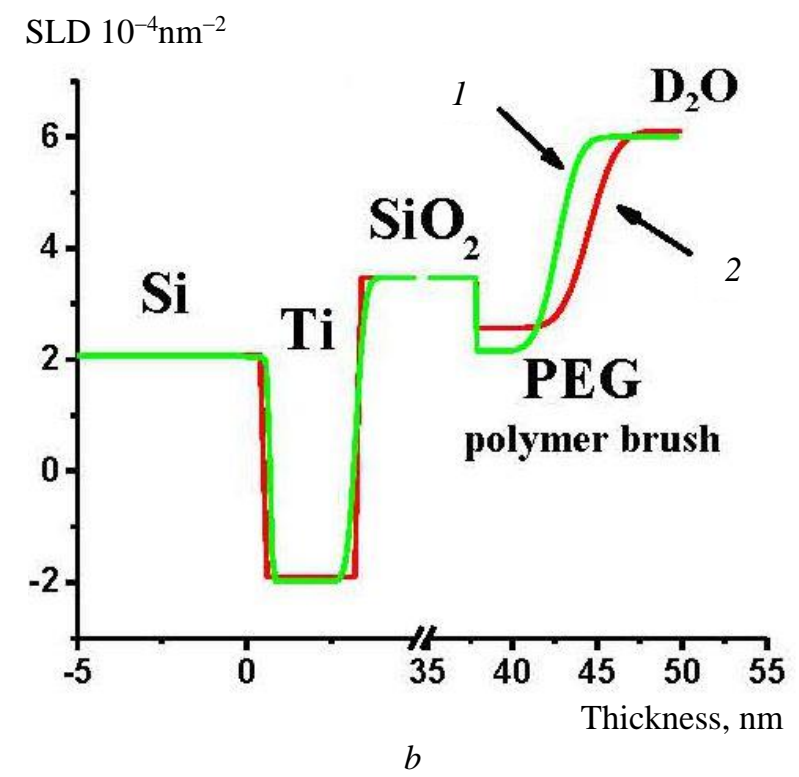

Fig. 3. Neutron reflectometry data: $a$ - reflectivity from $\mathrm{Si} / \mathrm{Ti} / \mathrm{SiO}_{2}$ substrate in the liquid cell with heavy water (1), from PEG polymer brush system on the substrate in the liquid cell (2), and after addition of 0.2 vol. \% solution of DBSA in heavy water (3). Solid lines show approximating curves; $b$ - SLD depth profiles corresponding to the model reflectivity curves for the heavy water solutions without DBSA (1) and after the addition of DBSA (2). (See color Figure on the journal website.)

In Fig. 4, $a$ the SANS curves from different bulk solutions related to the studied interfaces are compared [7]. The curves are given for (1) pure polymer solutions in heavy water (PEG, molecular weight of $20 \mathrm{kDa}$, concentration of 3 vol. \%), pure surfactant solutions in heavy water (DBSA, concentration of 3 vol. \%), and (3) mixed solutions in heavy water with PEG and DBSA micelles. The bell-shaped scattering curves for the micellar systems show the presence of electrostatic repulsion between charged micelles, which leads to the appearance of the systematic correlations in the arrangement of micelles in solution with a certain average distance between them (inversed to the peak position). It can be seen that the position of the scattering intensity maximum for the DBSA systems with PEG is shifted to the right; at the same time, the SANS curve itself is not the sum of the scattering intensities for PEG and DBSA components measured separately. Such changes in the SANS curves are typical for micellar systems, in which the average distance between micelles decreases together with changes in the shape of the micelle itself in the presence of the PEG polymer $[8,17]$.

The SANS curves were modeled in accordance with the general equation [26]

$$
(q)=I_{0} P(q) S(q)+B k g
$$

where $I_{0}=n(\Delta \rho)^{2} V^{2}$ - forward scattering intensity; $n$ is the particle number concentration; $V$ is the particle volume; $\Delta \rho$ is the SLD contrast between the particle and solution medium; $B k g$ is the background. The scattering intensity on an isolated particle is described by the form-factor $P(q)$, which is determined by the Fourier transform of the SLD distribution function in the particle. The structure-factor $S(q)$ describes the scattering from correlations caused 
by the particle interaction. In the case of anionic surfactant micelles, the form-factor of an ellipsoid of revolution with the interaction potential of the screened spheres was used [27].

It is well known that due to molecular forces between neutral polymers and micelles of ionic surfactants, supramolecular aggregates can form [4, 28]. Such aggregates have the structure of a polymer chain, to which up to several micelles are bound [6]. The structure of DBSA-PEG molecular aggregates

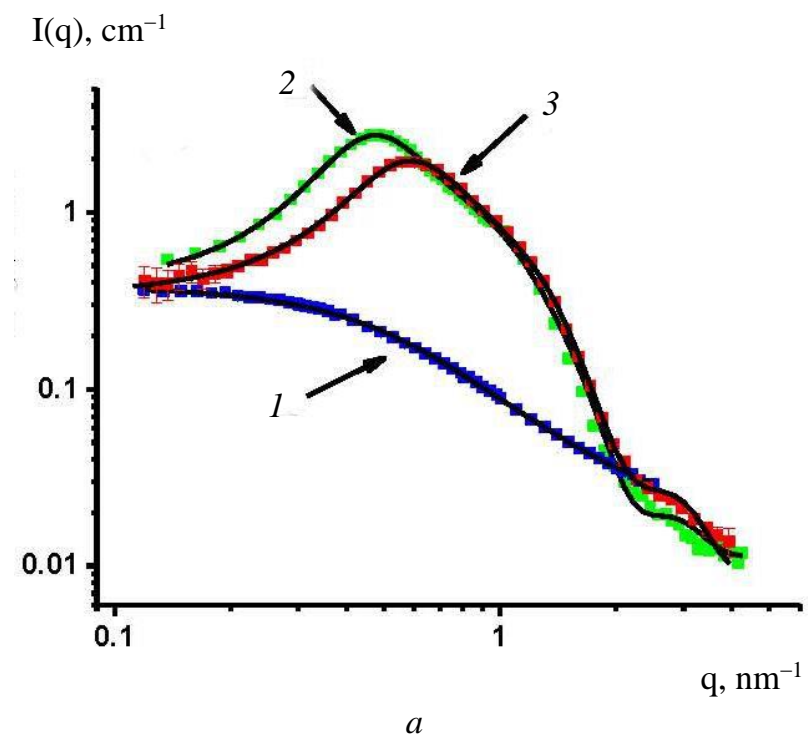

was studied by the SANS method at low concentrations of free micelles [17]. Fig. 4, $b$ shows the experimental SANS curves for the DBSA-PEG associates at different molecular weights of the polymer. The formation of a supramolecular associate occurs in systems with polymer molecular mass $M_{n}>10 \mathrm{kDa}$ $[17,29]$, in this case, a second correlation peak appears in the SANS curve at $q \sim 0.2 \mathrm{~nm}^{-1}$, which corresponds to the average distance between molecular aggregates.

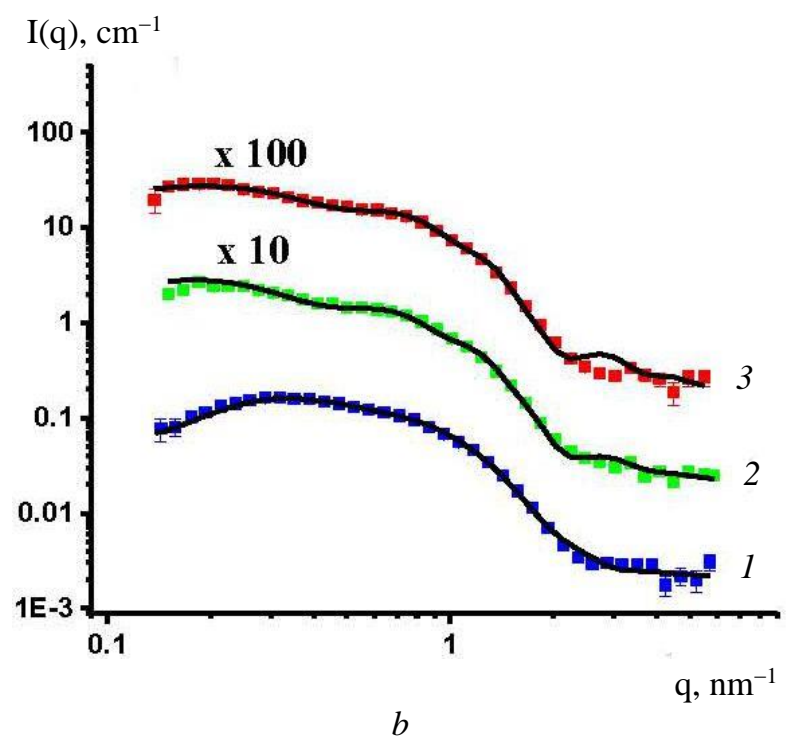

Fig. 4. SANS data. $a$ - PEG $20 \mathrm{kDa}$ addition effect on the DBSA micellar system: 1 - scattering from PEG $20 \mathrm{kDa}$ solution with 3 vol. $\%$ concentration; 2 - scattering from DBSA 3 vol. \% solution; 3 - scattering from DBSA 3 vol. \% + PEG 3 vol. \% mixture solution (3) [7]; $b$ - scattering from the surfactant-polymer complexes at low concentrations of free micelles in solutions with PEG 0.05 vol. $\%$ + DBSA 0.2 vol. $\%$ for different molecular weight of polymer $1 \mathrm{kDa}$ (1), $20 \mathrm{kDa}(2), 30 \mathrm{kDa}(3)$ (vertically shifted curves) [17]. Solid lines show the model curves. (See color Figure on the journal website.)
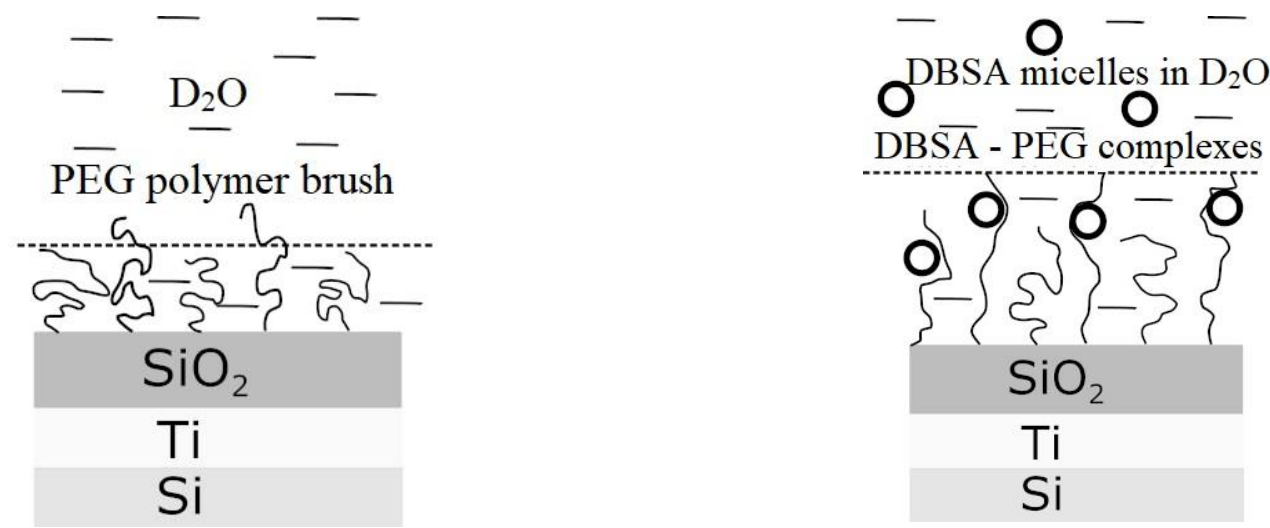

Fig. 5. Schematic representation of substrate layers with a polymer brush system in deuterated water (left), the formation of surfactant - polymer complexes in polymer brush systems (right).

The complex formation of charged micelles with a neutral polymer is accompanied by stretching of the polymer chain [4]. Thus, the average distance between micelles in the composition of one complex reaches $7 \mathrm{~nm}$ for a polymer with a molecular weight of $20 \mathrm{kDa}$ for which the gyration radius is $4.3 \mathrm{~nm}$ without micelles $[17,25]$. Thus, the change in the height of the PEG polymer brush which is in contact with the micellar solution of DBSA in the NR experiment is reasonably explained by the attachment of micelles to the polymer, which causes the stretching of the polymer chain. This effect was studied theoretically [14, 15]; this was also observed earlier for sodium dodecyl sulfate and sodium dodecylbenzene sulphonate micelles interacting with poly (ethylene glycol) polymer brushes [13]. It is important to note 
that the ability of micelles to bind to a polymer brush largely depends on the energy of formation of surfactant-polymer associates, as well as on the polymer brush tethering density. The formation of DBSAPEG associates in the dense PEG polymer brush is schematically shown in Fig. 5.

It should also be noted that there is a well-known non-cooperative mechanism of DBSA-PEG interaction associated with the formation of hydrogen bonds between the polar part of DBSA and the polymer link [30]. In this case, under certain conditions, the formation of associates is possible, the structure of which is qualitatively different from the structure of micellar aggregates. Namely, the formation of supramolecular structures with lamella morphology occurs. The structure of DBSA complexes in the dense medium of the PEG polymer brush under study remains unexplored and requires further investigations. It is well known that due to the screening of the electrostatic repulsion between the surfactant polar groups in the micelles, the critical packing parameter changes, and, along with the formation of spherical micelles, the formation of cylindrical micelles or lamellae is also possible in the polymer brushes [16].

\section{Conclusions}

The polymer brush system of poly (ethylene glycol) with a molecular weight of $20 \mathrm{kDa}$ was synthesized on a silica substrate using the "grafting to" method with a final average distance between the points of attachment to the substrate of $\sim 4.4 \mathrm{~nm}$. A dense polymer layer with a thickness of $\sim 2 \mathrm{~nm}$ was detected. Experimental curves for polymer brush systems were obtained by neutron reflectometry in the geometry of an incident beam from a substrate into a liquid. From the obtained scattering length density profile of poly (ethylene glycol), the polymer brush revealed an increase in the effective height from 6.6 to $9.2 \mathrm{~nm}$ when adding dodecylbenzenesulfonate acid to the system. We attribute the change in the thickness of the poly (ethylene glycol) polymer brush to the cooperative interaction of micelles with the polymer chain, which has so far been observed in bulk solutions of dodecylbenzene acid and high molecular weight poly (ethylene glycol).

\section{REFERENCES}

1. S.T. Milner. Polymer brushes. Science 251 (1991) 905.

2. B. Zdyrko, I. Luzinov. Polymer brushes by the "grafting to" method. Macromol. Rapid Commun. 32 (2011) 859 .

3. W.J. Brittain, S. Minko. A structural definition of polymer brushes. J. Polym. Sci. Part A Polym. Chem. 45 (2007) 3505.

4. Y.J. Nikas, D. Blankschtein. Complexation of Nonionic Polymers and Surfactants in Dilute Aqueous Solutions. Langmuir 10 (1994) 3512.

5. K.C. Tam, E. Wyn-Jones. Insights on polymer surfactant complex structures during the binding of surfactants to polymers as measured by equilibrium and structural techniques. Chem. Soc. Rev. 35 (2006) 693.

6. L.T. Lee. Polymer-surfactant interactions: Neutron scattering and reflectivity. Curr. Opin. Colloid Interface Sci. 4 (1999) 205.

7. O.P. Artykulnyi et al. Impact of poly (ethylene glycol) on the structure and interaction parameters of aqueous micellar solutions of anionic surfactants. J. Mol. Liq. 276 (2019) 806.

8. O.P. Artykulnyi et al. On the impact of polyethylene glycol on the structure of aqueous micellar solutions of sodium oleate according to small-angle neutron scattering. J. Surf. Investig. 12 (2018) 1142.

9. J. Philip et al. Three Distinct Scenarios under Polymer, Surfactant, and Colloidal Interaction. Macromolecules 36 (2003) 9230.

10. B. Cattoz et al. Manipulating interfacial polymer structures through mixed surfactant adsorption and complexation. Langmuir 28 (2012) 6282.

11. E. Tombácz et al. Surfactant double layer stabilized magnetic nanofluids for biomedical application. J. Phys. Condens. Matter. 20 (2008) 204103.

12. V. Závišová et al. Magnetic fluid poly (ethylene glycol) with moderate anticancer activity. J. Magn. Magn. Mat. 323 (2011) 1408.

13. W.M. de Vos et al. Adsorption of anionic surfactants in a nonionic polymer brush experiments, comparison with mean-field theory, and implications for brushparticle interaction. Langmuir 25 (2009) 9252.

14. H. Wang et al. Molecular dynamics study of the adsorption of anionic surfactant in a nonionic polymer brush. J. Mol. Model. 20 (2014) 1.

15. E.P.K. Currie et al. Grafted polymers with annealed excluded volume: A model for surfactant association in brushes. Eur. Phys. J. E 1 (2000) 27.

16. M. Moglianetti et al. A neutron reflectivity study of surfactant self-assembly in weak polyelectrolyte brushes at the sapphire-water interface. Langmuir 27 (2011) 4489.

17. O.P. Artykulnyi et al. Structural investigations of poly(ethylene glycol)-dodecylbenzenesulfonic acid complexes in aqueous solutions. J. Mol. Liq. 308 (2020) 113045.

18. V.I. Petrenko et al. On Enhancement of the Adsorption-Layer Effect at the Metallic ElectrodeLiquid Electrolyte Interface in Specular Neutron Reflectometry Experiments. J. Surf. Investig. 12 (2018) 651.

19. S.D. Chandradoss et al. Surface passivation for single-molecule protein studies. J. Vis. Exp. 86 (2014) 50549.

20. Y. Han et al. Surface activation of thin silicon oxides by wet cleaning and silanization. Thin Solid Films 510 (2006) 175 
21. M.V. Avdeev et al. Neutron time-of-flight reflectometer GRAINS with horizontal sample plane at the IBR-2 reactor: Possibilities and prospects. Crystallogr. Reports 62 (2017) 1002.

22. V. Ananiev et al. The world's first pelletized cold neutron moderator at a neutron scattering facility. Nucl. Instruments Methods B 320 (2014) 70.

23. I.V. Gapon et al. Structure analysis of aqueous ferrofluids at interface with silicon: Neutron reflectometry data. J. Phys: Conf. Ser. 848 (2017) 012015.

24. A. Nelson. Co-refinement of multiple-contrast neutron/X-ray reflectivity data using MOTOFIT. J. Appl. Crystallogr. 39 (2006) 273.

25. K.L. Linegar et al. Hydrodynamic radius of polyethylene glycol in solution obtained by dynamic light scattering. Colloid J. 72 (2010) 279.

26. J.S. Pedersen. Analysis of small-angle scattering data from colloids and polymer solutions: Modeling and least-squares fitting. Adv. Colloid Interface Sci. 70 (1997) 172.

27. L.A. Bulavin et al. Measurements of structural and electrostatic parameters and surface tension of micelles of an ionic surfactant versus concentration, ionic strength of solution and temperature by smallangle neutron scattering. Colloids Surf. A: Physicochem. Eng. Asp. 131 (1998) 137.

28. E. Ruckenstein, G. Huber, H. Hoffmann. Surfactant Aggregation in the Presence of Polymers. Langmuir 3 (1987) 382.

29. R. Mészáros, I. Varga, T. Gilányi. Effect of polymer molecular weight on the polymer/surfactant interaction. J. Phys. Chem. B 109 (2005) 13538.

30. H.L. Chen, C.C. Ko, T.L. Lin. Self-assembly in the bulk complexes of poly(ethylene-oxide) with amphiphilic dodecylbenzenesulfonic acid. Langmuir 18 (2002) 5619.

$$
\begin{aligned}
& \text { О. П. Артикульний }{ }^{1,2, *} \text {, М. М. Авдєєв }{ }^{2} \text {, С. М. Косячкін }{ }^{1,2,3} \text {, } \\
& \text { В. І. Петренко }{ }^{4,5} \text {, І. Сафарік6, Л. А. Булавін }{ }^{1}
\end{aligned}
$$

\section{НЕЙТРОННІ ДОСЛІДЖЕННЯ ВЗАСМОДІЇ МІЖ МІЦЕЛАМИ АНІОННОЇ ПОВЕРХНЕВО-АКТИВНОЇ РЕЧОВИНИ ТА СИСТЕМОЮ ПОЛІМЕРНОЇ ЩІТКИ ПОЛІЕТИЛЕНГЛККОЛЮ}

Методом дзеркальної нейтронної рефлектометрії було досліджено системи полімерної щітки нейтрального полімеру поліетиленгліколю з молекулярною масою $M_{w}=20$ кДа на поверхні кремнієвої підкладинки у водному середовищі. Виявлено ефект зміни структури профіля густини полімерної щітки при взаємодії ланцюгів полімеру 3 міцелами аніонної поверхнево-активної речовини додецилбензолсульфонатної кислоти. Було показано, що ефект, який спостерігався, пов'язаний із процесом утворення молекулярних комплексів між полімером та міцелами в об’ємі розчину, що був нами досліджений раніше методом малокутового розсіяння нейтронів у широкому діапазоні концентрацій поверхнево-активної речовини при різній молекулярній масі полімеру. Щільність насадження молекул полімеру на кремнієву підкладинку було досліджено методами рентгенівської рефлектометрії та скануючої атомно-силової мікроскопії.

Ключові слова: міцели, аніонна поверхнево-активна речовина, поліетиленгліколь, полімерна щітка, нейтронна рефлектометрія, малокутове розсіяння нейтронів.

Надійшла/Received 28.05.2021 